\title{
FINDING HOTS-BASED MATHEMATICAL LEARNING IN ELEMENTARY SCHOOL STUDENTS
}

\author{
Anesa Surya, Sularmi, Siti Istiyati, Rahmat Fajar Prakoso \\ Universitas Sebelas Maret \\ anesasurya@staff.uns.ac.id
}

\section{Article History}

accepted 09/07/2018

approved 01/08/2018

published 17/09/2018

\section{Keywords}

Higher Order Thinking

Skills (HOTS), teachers' skills

\begin{abstract}
Pendekatan pembelajaran pada era sekarang ini sudah bergeser pada pembelajaran yang aktif, kreatif, kritis dan menyenangkan, sehingga akan tercipta pembelajaran yang bermakna. Hal tersebut dilandasi oleh tantangan pendidikan abad 21, yang menuntut siswa agar memiliki keterampilan berkomunikasi dan penguasaan ilmu pengetahuan teknologi melalui proses pembelajaran. Pelaksanaan pendidikan di Indonesia saat ini sudah mengarah pada tantangan abad 21, hal tersebut dibuktikan dari diterapkannya Kurikulum 2013 yang menekankan pada proses pembelajaran. Kendala yang ditemukan selama ini adalah masih sulit sekali melatih keterampilan berpikir tingkat tinggi pada siswa. Hal tersebut tidak hanya ditemui pada tingkatan sekolah lanjut, akan tetapi dari tingkatan sekolah dasar. Pentingnya melatih keterampilan berpikir tingkat tinggi pada siswa sejak tingkatan sekolah dasar adalah untuk mengembangkan pola pemikiran berkelanjutan pada siswa. Namun, kecenderungan pembelajaran matematika yang diajarkan saat ini masih menekankan pada keterampilan berpikir tingkat rendah. Indikasinya bisa dilihat dari pembelajaran selalu menggunakan metode menghafal dari buku. Selain itu, kebanyakan guru masih sulit mengajarkan dan membiasakan cara berpikir tingkat tinggi pada peserta didiknya. Hal tersebut dikarenakan masih kurangnya pengetahuan guru mengenai implementasi pembelajaran HOTS. Pada dasarnya untuk melatih keterampilan berpikir tingkat tinggi diperlukan keterampilan berpikir tingkat rendah sebagai dasar, tetapi akan lebih baik keterampilan berpikir tingkat tinggi mulai dilatih sejak siswa tingkat sekolah dasar. Keterampilan berpikir tingkat tinggi ini akan membuat siswa mampu meningkatkan kemampuan berkomunikasi dan penguasaan ilmu pengetahuan sesuai dengan tantangan pendidikan abad 21.
\end{abstract}

Social, Humanities, and Education Studies (SHEs): Conference Series https://jurnal.uns.ac.id/shes

p-ISSN 2620-9284 e-ISSN 2620-9292 


\section{PENDAHULUAN}

Implementasi Undang-undang No. 20 tahun 2003 tentang Sistem Pendidikan Nasional adalah mengembangkan kemampuan atau skill yang berguna untuk menyiapkan sumber daya manusia yang mampu menjawab tantangan zaman. Tantangan pendidikan abad 21 seperti saat ini adalah untuk untuk menyiapkan sumber daya manusia agar memiliki kemampuan berkomunikasi dan penguasaan ilmu pengetahuan teknologi melalui proses pembelajaran. Ditjen Pendidikan Dasar dan Menengah (2017: 6) dalam Panduan Implementasi Kecakapan Abad 21 juga menegaskan bahwa kompetensi kecakapan abad 21 meliputi 1) Kecakapan berpikir kritis dan pemecahan masalah, 2) Kecakapan berkomunikasi, 3) Kreativitas dan inovasi, 4) Kolaborasi. Keempat kecakapan atau kemampuan peserta didik tersebut dibina dan dikembangkan di dalam setiap mata pelajaran. Matematika sebagai salah satu mata pelajaran memiliki peran untuk mengembangkan kemampuan berpikir kritis dan pemecahan masalah.

Permasalahan dalam pembelajaran matematika yang terjadi saat ini berkenaan dengan sifat pembelajaran matematika yang abstrak, sehingga peserta didik sulit untuk memahaminya. Dampaknya peserta didik kurang berminat dengan pelajaran matematika dan menganggap dirinya tidak mampu mempelajari matematika. Menurut pendapat Shadiq dan Mustajab (2011: 1) sebagian siswa beranggapan bahwa dirinya tidak memiliki bakat untuk mempelajari matematika. Artinya siswa seperti sudah memvonis dirinya untuk tidak akan mampu mempelajari matematika, karena meskipun siswa mempelajari matematika tetap tidak akan berhasil mempelajarinya. Hal tersebut sangat berpengaruh pada pencapaian siswa pada pelajaran matematika. Indikatornya bisa dilihat dari penelitian yang dilakukan oleh Programme for International Student Assessment (PISA) tahun 2015 dalam www.pisa.oecd.org yang menunjukkan bahwa skor rata-rata matematika Indonesia yakni 386. Skor tersebut masih jauh dari skor ratarata yang dikeluarkan PISA yakni 490, sehingga dengan skor tersebut menempatkan Indonesia di urutan 63 dari 69 negara yang dievaluasi. Hasil penelitian dari PISA menunjukkan bahwa kebanyakan siswa di Indonesia masih sulit memahami konsep dalam materi pembelajaran matematika.

Melihat kenyataan tersebut, perlu adanya usaha dalam pelaksanaan pembelajaran yang mampu melatih penalaran siswa. Pembelajaran yang dilaksanakan harus bisa mencakup empat kecakapan abad 21 seperti yang telah dijelaskan di atas. Salah satu cara yakni dengan optimalisasi penerapan pembelajaran berbasis Higher Order Thinking Skill (HOTS). Penerapan pembelajaran berbasis HOTS ini dilaksanakan mulai dari tingkat sekolah dasar sebagai landasan pemikiran siswa. Permasalahan yang terjadi saat ini mengenai pembelajaran berbasis HOTS antara lain berkenaan dengan kompetensi guru sekolah dasar dalam menciptakan pembelajaran matematika yang dapat melatih kemampuan berpikir tingkat tinggi pada siswa sekolah dasar.

\section{Karakteristik Siswa Sekolah Dasar}

\section{HASIL DAN PEMBAHASAN}

Pembelajaran di Sekolah Dasar (SD) menjadi pondasi untuk melanjutkan pembelajaran selanjutnya. Pentingnya pembelajaran di SD harus menjadi pertimbangan berbagai pihak yang berhubungan dengan pendidikan di sekolah dasar. Oleh sebab itu sebelum melakukan kegiatan penelitian, seorang peneliti harus memahami karakteristik peserta didik di sekolah dasar. Menurut Nasution (1993) masa usia sekolah dasar sebagai masa kanak-kanak akhir yang berlangsung dari usia enam tahun hingga kira-kira sebelas atau dua belas tahun (Djamarah, 2008: 123). Pada 
masa usia inilah peserta didik mengalami perkembangan, di antaranya perkembangan kognitif, perkembangan bahasa, dan perkembangan sosial. Pada usia 6 sampai 12 tahun inilah sering disebut dengan masa sekolah, karena pada usia 6 tahun anak mulai menerima pendidikan formal. Berdasarkan rentang usianya, peserta didik sekolah dasar dibagi menjadi 2 yaitu kelas rendah dan kelas tinggi. Usia peserta didik kelas rendah berada pada rentang usia dini yaitu, kelas satu sampai kelas tiga. Sedangkan usia peserta didik kelas tinggi yaitu, kelas empat sampai kelas enam.

Usia peserta didik kelas rendah adalah masa peralihan dari masa kanak-kanak. Pada masa ini sebagian besar peserta didik masih belum bisa terbiasa gaya belajar pendidikan formal. Oleh sebab itu, sistem pembelajaran pada kelas satu sampai kelas tiga menggunakan tema. Pada pembelajaran yang berbasis tema, peserta didik diajak belajar sambil bermain. Materi pembelajaran juga masih berkaitan dengan kehidupan keseharian peserta didik. Di dalamnya terdapat pembiasaan kebiasaan baik, penanaman karakter, dan pengenalan lingkungan sekitar peserta didik.

Beberapa sifat peserta didik kelas rendah menurut Djamarah (2008: 124) antara lain: 1) adanya korelasi positif yang tinggi antara keadaan kesehatan pertumbuhan jasmani dan prestasi sekolah, 2) adanya sikap yang cenderung untuk mematuhi peraturan-peraturan permainan yang tradisional, 3) ada kecenderungan memuji sendiri, 4) suka membanding-bandingkan dirinya dengan anak lain, kalau hal itu dirasanya menguntungkan untuk meremehkan anak lain, 5) kalau tidak dapat menyelesaikan sesuatu soal, maka soal itu dianggapnya tidak penting. Apabila dilihat dari pernyataan Djamarah di atas, usia peserta didik kelas rendah masih cenderung polos. Polos di sini artinya, peserta didik masih perlu bimbingan untuk mengarahkan apa yang baik dan apa saja yang buruk. Oleh karena itu, perlu pengawasan dan pengontrolan peserta didik baik di sekolah maupun di rumah.

Karakter peserta didik pada masa kelas rendah berbeda dengan karakter anak pada kelas tinggi. Hal ini dapat dilihat dalam proses pembelajaran anak. Pada peserta didik kelas rendah belum dapat mengembangkan keterampilan kognitifnya secara penuh, sedangkan peserta didik di kelas tinggi sudah dapat berfikir, berkreasi secara luas .Beberapa sifat peserta didik kelas tinggi menurut Djamarah (2008: 125) antara lain: 1) adanya minat terhadap kehidupan praktis sehari-hari yang konkrit, hal ini menimbulkan adanya kecenderungan untuk membandingkan pekerjaan-pekerjaan yang praktis, 2) sangat realistik, ingin tahu dan ingin belajar, 3) menjelang akhir masa ini telah ada minat terhadap hal-hal dan mata pelajaran khusus, yang oleh ahli-ahli yang mengikuti teori faktor ditafsirkan sebagai mulai menonjolnya faktor-faktor, 4) sampai kira-kira umur 11 tahun anak membutuhkan guru atau orang-orang dewasa lainnya, untuk menyelesaikan tugasnya dan memenuhi keinginannya, 5) anak-anak pada masa ini gemar membentuk kelompok sebaya, biasanya untuk dapat bermain bersama-sama.

Berdasarkan uraian di atas, usia peserta didik kelas tinggi berada pada periode operasi konkret, pada tahap ini peserta didik mengembangkan pemikiran logis, masih sangat terikat pada fakta-fakta perseptual. Artinya peserta didik sudah mampu berpikir logis dalam memahami sesuatu, tetapi masih terbatas pada obyek-obyek konkret. 


\section{Pembelajaran Matematika di Sekolah Dasar}

Pembelajaran merupakan suatu proses interaksi yang terjadi antara peserta didik, pendidik, dan sumber belajar dalam sebuah situasi belajar. Interaksi tersebut ditujukan untuk mengembangkan seluruh aspek potensi yang ada pada diri peserta didik, antara lain aspek kognitif, afektif, dan berimplikasi pada aspek psikomotor. Pembelajaran yang dilakukan bukan sekedar mentransfer informasi dari sumber belajar ke peserta didik saja, namun peserta didik harus berperan aktif dalam sebuah pembelajaran sehingga pembelajaran akan bermakna. Kebermaknaan pembelajaran tersebut berguna sebagai pengembangan potensi dalam diri peserta didik, yang pada akhirnya digunakan peserta didik untuk bekal di masyarakat. Menurut pendapat Susanto (2014: 183) penyelenggaraan pendidikan di tingkat sekolah dasar bertujuan memberi bekal kepada siswa untuk hidup bermasyarakat dan dapat melanjutkan pendidikan ke jenjang yang lebih tinggi. Hal tersebut berlaku juga pada pembelajaran matematika, dengan demikian pembelajaran matematika di sekolah dasar dimaksudkan agar peserta didik tidak hanya terampil menggunakan matematika saja. Namun dapat memberikan bekal kepada peserta didik dengan tekanan penataan nalar dalam penerapan matematika di kehidupan sehari-hari.

Matematika merupakan ilmu yang mempelajari sesuatu yang pasti. Matematika berasal dari bahasa Latin, Manthanein atau mathema yang berarti "belajar atau hal yang dipelajari" sedangkan dalam bahasa Belanda, matematika disebut wiskunde atau ilmu pasti, yang kesemuanya berkaitan dengan penalaran (Depdiknas, Susanto, 2014 : 184). Matematika dikenal dengan ilmu pasti karena dikenal dengan penalaran induktif (induksi) dan penalaran deduktif (deduksi). Induksi merupakan suatu proses berpikir untuk menarik kesimpulan atau membuat suatu pernyataan baru yang bersifat umum (general). Menurut Shadiq (2014:6), deduksi merupakan suatu cara penarikan kesimpulan dari pertanyaan atau fakta-fakta yang dianggap benar dengan menggunakan logika.

Menurut pendapat Susanto (2014: 183) matematika merupakan salah satu disiplin ilmu yang dapat meningkatkan kemampuan berpikir dan beragumentasi, memberikan kontribusi dalam penyelesaian masalah sehari-hari dan dalam dunia kerja, serta memberikan dukungan dalam pengembangan ilmu pengetahuan dan teknologi. Matematika merupakan fenomena yang berbeda dengan fenomena lain karena menunjukan sifat-sifat yang dapat dilambangkan dalam bilangan dan angkaangka serta dalam keterhubungan angka-angka dengan geometri (Hamzah \& Muhlisrarini, 2014:52). Matematika dijadikan sebagai salah satu bidang studi yang ada dalam semua jenjang pendidikan, mulai dari taman kanak-kanak yang diajarkan secara informal dan tingkat sekolah dasar hingga perguruan tinggi.

Depdiknas (2001: 9) mengungkapkan bahwa ruang lingkup mata pelajaran matematika mencakup komponen kompetensi umum yang meliputi aspek-aspek sebagai berikut; 1) Melakukan operasi hitung penjumlahan, pengurangan, perkalian, pembagian beserta operasi campurannya, termasuk yang melibatkan pecahan; 2) Menentukan sifat dan unsur berbagai bangun datar dan bangun ruang sederhana, termasuk penggunaan sudut, keliling, luas, dan volume; 3) Menentukan sifat simetri, kesebangunan dan sistem koordinat; 4) Menggunakan pengukuran: satuan, kesetaraan antarsatuan, dan penaksiran pengukuran; 5) Menentukan dan menafsirkan data sederhana, seperti: ukuran tertinggi, terendah, rata-rata, modus, mengumpulkan, 
dan menyajikannya; 6) Memecahkan masalah, melakukan penalaran, dan mengomunikasikan gagasan secara matematika.

Matematika merupakan ide-ide abstrak yang berisi simbol-simbol, maka konsep-konsep dalam matematika harus dipahami terlebih dahulu sehingga daya penalaran peserta didik juga bisa berkembang. Dalam kurikulum Depdiknas 2004 disebutkan bahwa standar kompetensi matematika di sekolah dasar yang harus dimiliki peserta didik setelah melakukan pembelajaran bukanlah penguasaan matematika, namun yang diperlukan ialah dapat memahami dunia sekitar, mampu bersaing, dan berhasil dalam kehidupan. Artinya, pembelajaran matematika yang memiliki aturan dan bahasa yang baku akan melatih daya penalaran siswa. Lebih lanjut, penalaran yang ada pada siswa tersebut berguna dan akan diaplikasikan pada kehidupan sehari-hari.

\section{HOTS pada Matematika}

Higher-order thinking skills (HOTS) adalah meminimalisir kemampuan mengingat kembali informasi (recall) dan asesmen lebih mengukur kemampuan. Higher-order thinking termasuk menunjukkan pemahaman akan informasi dan bernalar bukan sekedar mengingat kembali/recall informasi. Higher order thinking tidak berarti soal yang lebih sulit daripada soal recall. HOTS merupakan suatu ketrampilan kognitif tingkat tinggi dan sering disebut sebagai ketrampilan berpikir kritis. HOTS dikatakan sebagai ketrampilan kognitif tingkat tinggi karena diperlukannya diskusi dan berpikir secara lebih kreatif dalam pemecahan masalah. (Facione, The Delphi Report, 1990).

Menurut Lewis \& Smith (1993: 136) juga menyatakan bahwa: "Higher order thinking occurs when a person takes new information and information stored in memory and interrelates and/ or rearanges and extends this information to achieve a purpose or find possible answers in perplexing situations". Berdasarkan pendapat ini, dapat disimpulkan bahwa berpikir tingkat tinggi pada seseorang akan muncul ketika informasi baru yang disimpan dalam ingatan akan saling berkaitan kembali untuk mencari jawaban pada saat dihadapkan pada kondisi yang membingungkan.

Berbeda dengan yang dikemukakan (Tankersley, 2003) menyatakan bahwa berpikir tingkat tinggi merupakan kemampuan untuk membedakan informasi penting atau konsep inti dari apa yang menarik. Hal tersebut berari bahwa seseorang harus mengetahui betul konsep yang di baca. Klasifikasi dari berpikir tingkat tinggi yaitu evaluasi, sintesis, analisis dan interpretasi. Pada dasarnya kemapuan berpikir tingkat tinggi tidak dapat ditemui pada pembelajaran yang terlalu berpusat pada guru. Guru menjelaskan dan siswa mendengarkan tidak dapat menumbuhkan ketrampilan berpikir siswa. Siswa belajar dengan bantuan media yang sesuai dan menarik dapat mendorong siswa untuk berpikir lebih kreatif. Pada umumnya ketrampilan berpikir tingkat tinggi terjadi pada mata pelajaran matematika. Siswa diminta untuk memecahkan soal cerita.

Sedangkan menurut Brookhart (2010: 3) keterampilan berpikir tingkat tinggi dikategorikan kedalam 3 bagian yaitu: (1) "... define higher order thinking in terms of transfer"; (2) "... define it in terms of critical thinking”; dan (3) "... define it in terms of problem solving". Dalam hal ini definisi keterampilan berpikir tingkat tinggi dikategorikan kedalam 3 bagian yaitu (1) sebagai bentuk hasil transfer hasil belajar, (2) sebagai bentuk berpikir kritis, dan (3) sebagai proses pemecahan masalah. 
Pengimplementasian ketrampilan berpikir tingkat tinggi pada pembelajaran matematika sekolah dasar tidak mudah dilakukan oleh guru, perlu ada usaha yang optimal dalam melaksanakannya. Oleh sebab itu perlu adanya sistem yang mendukung dalam pelaksanaannya di dalam kelas. Untuk itu tugas guru dalam kelas memiliki peran mengatur dan memotivasi siswa, menurut Conklin \& Manfro (2010: 18) cara-cara yang bisa digunakan adalah sebagai berikut:

1. Membuka pelajaran dengan pertanyaan-pertanyaan yang mengarah pada HOTS untuk mengawali diskusi dan debat.

2. Mengakhiri pelajaran dengan pertanyaan-pertanyaan HOTS yang digunakan sebagai alat penilaian.

3. Menempatkan aktivitas brainstorming pada pertengahan pelajaran untuk mendorong siswa menemukan ide dan berpikir kreatif.

4. Memberikan tugas berbasis open ended sebagai pekerjaan rumah untuk mengetahui kreativitas dan pemahaman mereka terhadap pelajaran yang sudah dipelajari.

Adapun strategi yang dapat diterapkan dalam pembelajaran Matematika untuk mengembangkan HOTS menurut King, Goodson \& Rohani (2010: 45) sebagai berikut:

1. Pembelajaran yang memberikan kesempatan pengulangan, elaborasi, organisasi, dan metakognisi.

2. Pembelajaran yang secara khusus berpusat kepada siswa

3. Presentasi tidak lebih dari lima belas menit dan disesuaikan antara proses menggali pengetahuan dan praktek dalam pembelajaran.

4. Guru atau siswa menghasilkan pertanyaan, masalah baru, dan pendekatan baru serta memperoleh jawaban yang belum dipelajari sebelumnya.

5. Pemberian umpan balik secara langsung, spesifik, dan menginformasikan kemajuan siswa.

6. Pembelajaran menggunakan diskusi kelompok kecil, tutor teman sebaya, dan pembelajaran kooperatif.

7. Aktivitas dalam pembelajaran melibatkan tugas-tugas yang menantang keinginan siswa, guru memotivasi siswa untuk mengerjakan tugas-tugas serta memberikan umpan balik terhadap hasil pekerjaan siswa.

\section{Pembuatan Soal Berbasis HOTS}

Penilaian terhadap keterampilan berpikir tingkat tinggi salah satunya bisa dilakukan dengan teknik tertulis. Penilaian tertulis baik digunakan untuk bisa melihat sejauh mana kemampuan siswa dalam menganalisis soal yang mengandung HOTS. Dalam penyusunan soal HOTS, perlu diperhatikan kaidah-kaidah penulisan soal antara lain sebagai berikut:

1. Perhatikan cakupan materi yang diharuskan untuk level pendidikan.

2. Perhatikan beberapa kompetensi yang diharapkan pada tiap level pendidikan yang kemudian diturunkan menjadi beberapa indikator dan tujuan dari pembelajaran berdasarkan anjuran yang tertuang pada kurikulum.

3. Penggunaan pengetahuan dasar untuk suatu cakupan materi sangat mungkin berbeda sesuai dengan level pendidikan.

4. Menggunakan pengetahuan atau kemampuan dasar nya untuk menyesaikan permasalahan yang ada. 
5. Dalam taksonomi Bloom tingkatan yang paling rendah dapat menjadi pengetahuan dasar untuk menjawab pertanyaan ke tingkatan selanjutnya.

6. Dianjurkan untuk menyediakan berbagai macam data (pernyataan, tabel, grafik, hasil dari percobaan yang dilakukan, laporan, bahan bacaan, hasil observasi, dII) sebagai stimulus untuk menjawab soal-soal HOTS.

7. Berbagai macam data yang disediakan seharusnya memberikan informasi kepada siswa merujuk kepada pengetahuan atau kemampuan dasar sehingga dapat diolah lebih lanjut.

8. Data yang diajukkan sebagai stimulus kepada siswa sedapat mungkin dibuat dengan situasi yang "autentik" atau nyata.

Selain itu, soal yang digunakan dalam pembelajaran HOTS harus pada kriteria soal-soal non rutin atau open ended. Menurut pendapat Suherman, dkk (2003: 123) soal terbuka atau open ended adalah soal yang berupa masalah yang diformulasikan memiliki beberapa jawaban yang benar atau biasa disebut problem tak lengkap. Soal open ended bertujuan untuk lebih menekankan siswa pada cara penyelesaian, analisis, dan sampai pada suatu jawaban. Sehingga tidak hanya menggunakan satu pendekatan atau metode dalam mendapatkan jawaban, namun beberapa pendekatan atau metode. Sifat "keterbukaan" dari problem itu dikatakan hilang apabila guru hanya mengajukan satu alternatif cara dalam menjawab permasalahan.

Dalam implementasinya, pembelajaran HOTS didukung dengan soal-soal open ended sebagai pemicu pemikiran siswa agar aktif dalam menumbuhkan keterampilan berpikir tingkat tinggi. Namun seringkali guru masih banyak menggunakan soal rutin dalam pelaksanaannya. Hal tersebut terjadi karena kebanyakan guru belum terbiasa mengembangkan soal non rutin atau open ended. Berikut ini merupakan contoh mengembangkan soal tertutup yang bisa dikembangkan menjadi soal terbuka.

Tabel 1

Mengubah Soal Tertutup menjadi Soal Terbuka

\begin{tabular}{|l|l|}
\hline \multicolumn{1}{|c|}{ Soal Tertutup } & \multicolumn{1}{|c|}{ Soal Terbuka } \\
\hline $\begin{array}{l}\text { Tentukan luas persegi panjang dengan } \\
\text { panjangnya } 5 \mathrm{~cm} \text { dan lebar } 6 \mathrm{~cm} ?\end{array}$ & $\begin{array}{l}\text { Buatlah ukuran panjang dan lebar } \\
\text { persegi panjang jika luasnya } 30 \mathrm{~cm}^{2} ?\end{array}$ \\
\hline Tentukan median dari $3,2,5,7,6 ?$ & $\begin{array}{l}\text { Susunlah angka yang mempunyai rata- } \\
\text { rata nya lebih dari mediannya? }\end{array}$ \\
\hline Berapakah hasil dari $12 \times 3 ?$ & $\begin{array}{l}\text { Sebutkan dua angka yang hasil } \\
\text { perkaliannya } 36 !\end{array}$ \\
\hline
\end{tabular}

\section{SIMPULAN}

Melatih keterampilan berpikir tingkat tinggi pada siswa sekolah dasar tidaklah mudah, karena perlu ada kaidah-kaidah yang harus diperhatikan. Guru sebagai faktor kunci dalam pembelajaran harus dapat menciptakan suasana belajar seperti yang diharapkan. Dalam hal ini dalam menciptakan suasana belajar matematika yang 
menumbuhkan keterampilan berpikir tingkat tinggi. Selain pengetahuan guru mengenai HOTS, guru juga harus bisa membuat soal-soal terbuka (open ended). Pentingnya hal tersebut karena soal merupakan instrumen pokok dalam pembelajaran, sehingga guru perlu melatih diri untuk membuat soal-soal terbuka. Guru perlu juga mengimplementasikan suatu pendekatan atau model pembelajaran yang dapat mendorong siswa berpikir tingkat tinggi, khususnya untuk melatih siswa berpikir kritis dan kreatif.

\section{DAFTAR PUSTAKA}

Brookhart, S.M. (2010). How to Assess Higher-Order Thinking Skills in Your Classroom. Virginia: ACSD Member Book.

Depdiknas. (2001). Standar Kompetensi Dasar Guru. Jakarta : Ditjen Dikti.

Ditjen Pendidikan Dasar dan Menengah. (2017). Panduan Implementasi Kecakapan Abad 21. Jakarta: Kementrian Pendidikan dan Kebudayaan Republik Indonesia

Djamarah, S.B. (2008). Psikologi Belajar. Jakarta: PT Rineka Cipta.

Facione. (1990). Critical Thinking: A Statement of Expert Consensus for Purposes of Educational Assessment and Instruction "The Delphi Report" Executive Summary. California: The California Academic Press.

Hamzah, A dan Muhlisrarini. (2014). Perencanaan dan Strategi Pembelajaran Matematika. Jakarta: Raja Grafindo Persada.

King, F.J, Goodson, L., \& Rohani, F. (2010). Higher Order Thinking Skills: Definition, Teaching Strategies, and Assesment. London: A Publication of The Educational Services Program.

Lewis, A \& Smith, D. (1993). Defining Higher Order Thingking: Theory Into Practice. College of Education (Versi elektronik), Volume 32 (3).

PISA. (2016). Programme for International Student Assessment 2015 Result in Focus. Diunduh pada 31 Juli 2017 pukul 13.46, dari www.oecd.org

Shadiq \& Mustajab. (2011). Penerapan Teori Belajar dalam Pembelajaran Matematika di SD. Yogyakarta: PPPPTK Matematika.

Shadiq, F. (2014). Pembelajaran Matematika: Cara Meningkatkan Kemampuan Berpikir Siswa. Yogyakarta: Graha IImu.

Suherman, Turmudi, \& Suryadi Rohayati. (2003). Strategi Pembelajaran Matematika Contemporer. Bandung: UPI.

Susanto, A. (2014). Teori Belajar Dan Pembelajaran di SD. Jakarta: Kencana Prenada Media Grup.

Tankersley, K. (2003). The Thread of Reading Strategy for Literacy Development. Virginia: Association for Supervision and Curriculum Development.

W.Conklin \& J. Manfro. (2010). Higher Order Thinking Skills to Develop 21st Century Learners. Huntington: Shell Education Publishing, Inc. 